\title{
ASTROCYTIC ROLE IN SYNAPSE FORMATION AFTER INJURY
}

\author{
Li, Ying, Li, Daqing and Raisman, Geoffrey
}

\begin{abstract}
In 1969 a paper entitled Neuronal plasticity in the septal nuclei of the adult rat proposed that new synapses are formed in the adult brain after injury (Raisman, 1969). The quantitative electron microscopic study of the timed responses to selective partial denervation of the neuropil of the adult rat septal nuclei after distant transection of the hippocampal efferent axons in the fimbria showed that the new synapses arise by sprouting of surviving adjacent synapses which selectively take over the previously denervated sites and thus restore the number of synapses to normal. This article presents the evidence for the role of perisynaptic astrocytic processes in the removal and formation of synapses and considers its significance as one of the three major divisions of the astrocytic surface in terms of the axonal responses to injury and regeneration.
\end{abstract}

\section{KEY WORDS}

PLASTICITY

REGENERATION

GLIA

IN VIVO

ELECTRON MICROSCOPY

\section{INTRODUCTION}

The decade following 1969 saw a gradual erosion of the previous entrenched view that the CNS was incapable of a positive response to injury. Inexorably the field was opening and plasticity after loss of synapses has broadened into a more general view that plasticity is an intrinsic core function of the brain and spinal cord. Plasticity occurs not only after injury (e.g. (Bareyre, Kerschensteiner, Raineteau, Mettenleiter, Weinmann, and Schwab, 2004) and during development (e.g. (Allen, 2013)) but also throughout adult life (e.g. (Kaas, Merzenich, and Killackey, 1983)). Plasticity is the ongoing, everyday function of the CNS; it lies at the heart of learning, of memory and of forgetting. Plasticity is a characteristic of all systems, sensory, motor, autonomic and cognitive. It is the core function that enables the individual to adapt to a constantly changing environment.

What has become clear in the years since 1969 is that the glial connectome (Douglas Fields, 2013), whose main representative is the astrocyte, is essential for the plasticity of the neuronal connectome (Clarke and Barres, 2013;Allen and Barres, 2005;Fields, Woo, and Basser, 2015;Perea, Sur, and Araque, 2014;Han, Chen, Wang, Windrem, Wang, Shanz, Xu, Oberheim, Bekar, Betstadt, Silva, Takano, Goldman, and Nedergaard, 2013; Heller and Rusakov, 2015). The involvement of astrocytes in synapse formation (Clarke and Barres, 2013) and synapse removal (Chung, Clarke, Wang, Stafford, Sher, Chakraborty, Joung, Foo, Thompson, Chen, Smith, and Barres, 2013) has largely come from situations with confrontation of neurons and astrocytes in culture. However, it is only electron microscopy that can afford the resolution needed to study the behaviour of the very thin perisynaptic astrocytic processes (PAPs; (Heller and Rusakov, 2015)). In this article we will review some of our electron microscopic evidence for the role of the PAPs in the formation of new synapses after injury. 


\section{OBSERVATIONS}

\section{Astrocytes in removal and formation of synapses}

Fig 1, taken from the material of the 1969 study, illustrates the PAPs associated with what much later came to be called the tripartite synapse (Haydon, 2001;Perea, Navarrete, and Araque, 2009). In 1973 we showed the PAPs to be an essential intermediary mediating both synapse removal and new synapse formation (Raisman and Field, 1973;Field and Raisman, 1983) in partially denervated neuropil. Fig. 2 shows how rapid and precisely targeted is the localised astrocytic hypertrophy to degenerating neuronal material (Cf. (Watts, Schuldiner, Perrino, Larsen, and Luo, 2004). Fig. 3 shows how the phagocytosis of degenerating terminals leads the astrocytic processes to come into contact with the denervated ('vacated') postsynaptic thickenings. The vacated postsynaptic sites are not lost. They remain identifiable, and marked by the astrocyte-apposed postsynaptic thickenings (s, in Figs 1-3)

The removal of the degenerating terminals and the apposition of the phagocytic astrocytic processes to the vacated postsynaptic thickenings are transient events. Within days the vacated thickenings are re-occupied by re-apposition of new presynaptic terminals formed by extension of local undamaged presynaptic terminals (Raisman, 1969). As reinnervation occurs there is an orchestrated withdrawal of the astrocytic processes and an ingrowth of newly formed axon terminals (Fig. 4). The original sites are precisely re-occupied and the number of synapses is restored to normal (Raisman and Field, 1973). The importance of astrocytic involvement in this process is shown by the fact that synaptogenesis is much delayed and reduced in areas of neuropil where the density of degeneration seems to have overwhelmed the phagocytic capacity of the local astrocytes (Field and Raisman, 1983).

\section{DISCUSSION}

Over the years PAPs have become recognised as a distinct astrocytic region which is involved in synapse formation. Confocal and laser scanning microscopy of brain slices has shown that astrocytic processes are rapidly motile (e.g. (Hirrlinger, Hulsmann, and Kirchhoff, 2004;Haber, Zhou, and Murai, 2006)) via mechanisms which include IP3, Ca2+, and an ezrin link from the actin cytoskeleton to the cell membrane (Tanaka, Shih, Gomi, Yoshida, Nakai, Ando, Furuichi, Mikoshiba, Semyanov, and Itohara, 2013;Molotkov, Zobova, Arcas, and Khiroug, 2013;Patrushev, Gavrilov, Turlapov, and Semyanov, 2013). It will be interesting to see how this motility is coordinated in time and space so as to produce the sequence of precision events needed for the removal of degenerating synapses and then the formation of new ones.

\section{The three astrocytic regions}

Although PAPs occupy the largest part of the surface membranes of astrocytes (Heller and Rusakov, 2015) it is important to keep in mind the other two major specialised surfaces - the inter-astrocytic surface that is involved in transmission through the astrocytic network, and the basal surface which is the interface between the nervous system and the other body tissues - fibroblasts and blood vessels. The astrocyte behaves as a coordinated cell - all three surfaces are involved in plasticity and in the response to CNS injury ( $\mathrm{Li}, \mathrm{Li}, \mathrm{Ibrahim}$, and Raisman, 2012). The molecular events at the three surfaces will be different. The control of events at the basal surface is an essential element in repair strategies. After tract injuries the interaction of the basal surface with the adjacent fibroblasts results in the formation of the astrocytic scar. 
Transplantation of olfactory ensheathing cells and olfactory nerve fibroblasts re-configures the scar arrangement so as to provide a pathway for cut axons to express their regenerative potential and restore function (Tabakow, Raisman, Fortuna, Czyz, Huber, Li, Szewczyk, Okurowski, Miedzybrodzki, Czapiga, Salomon, Halon, Li, Lipiec, Kulczyk, and Jarmundowicz, 2014).

\section{Reference List}

Allen NJ. 2013. Role of glia in developmental synapse formation. Curr Opin Neurobiol 23:1027-1033.

Allen NJ, Barres BA. 2005. Signaling between glia and neurons: focus on synaptic plasticity. Curr Opin Neurobiol 15:542-548.

Bareyre FM, Kerschensteiner M, Raineteau O, Mettenleiter TC, Weinmann O, Schwab ME. 2004. The injured spinal cord spontaneously forms a new intraspinal circuit in adult rats. Nat Neurosci 7:269-277.

Chung WS, Clarke LE, Wang GX, Stafford BK, Sher A, Chakraborty C, Joung J, Foo LC, Thompson A, Chen C, Smith SJ, Barres BA. 2013. Astrocytes mediate synapse elimination through MEGF10 and MERTK pathways. Nature 504:394-400.

Clarke LE, Barres BA. 2013. Emerging roles of astrocytes in neural circuit development. Nat Rev Neurosci 14:311-321.

Douglas Fields R. 2013. Map the other brain. Nature 501:25-27.

Field PM, Raisman G. 1983. Relative slowness of heterotypic synaptogenesis in the septal nuclei. Brain Res 272:83-99.

Fields RD, Woo DH, Basser PJ. 2015. Glial Regulation of the Neuronal Connectome through Local and Long-Distant Communication. Neuron 86:374-386.

Haber M, Zhou L, Murai KK. 2006. Cooperative astrocyte and dendritic spine dynamics at hippocampal excitatory synapses. J Neurosci 26:8881-8891.

Han X, Chen M, Wang F, Windrem M, Wang S, Shanz S, Xu Q, Oberheim NA, Bekar L, Betstadt S, Silva AJ, Takano T, Goldman SA, Nedergaard M. 2013. Forebrain engraftment by human glial progenitor cells enhances synaptic plasticity and learning in adult mice. Cell Stem Cell 12:342-353.

Haydon PG. 2001. GLIA: listening and talking to the synapse. Nat Rev Neurosci 2:185-193.

Heller JP, Rusakov DA. 2015. Morphological plasticity of astroglia: Understanding synaptic microenvironment. Glia 63:2133-2151.

Hirrlinger J, Hulsmann S, Kirchhoff F. 2004. Astroglial processes show spontaneous motility at active synaptic terminals in situ. Eur J Neurosci 20:2235-2239.

Kaas JH, Merzenich MM, Killackey HP. 1983. The reorganization of somatosensory cortex following peripheral nerve damage in adult and developing mammals. Annu Rev Neurosci 6:325-356. 
Li Y, Li D, Ibrahim A, Raisman G. 2012. Repair involves all three surfaces of the glial cell. Prog Brain Res 201:199-218.

Molotkov D, Zobova S, Arcas JM, Khiroug L. 2013. Calcium-induced outgrowth of astrocytic peripheral processes requires actin binding by Profilin-1. Cell Calcium 53:338-348.

Patrushev I, Gavrilov N, Turlapov V, Semyanov A. 2013. Subcellular location of astrocytic calcium stores favors extrasynaptic neuron-astrocyte communication. Cell Calcium 54:343349.

Perea G, Navarrete M, Araque A. 2009. Tripartite synapses: astrocytes process and control synaptic information. Trends Neurosci 32:421-431.

Perea G, Sur M, Araque A. 2014. Neuron-glia networks: integral gear of brain function. Front Cell Neurosci 8:378.

Peters A, Palay SL, Webster HF. 1976. The Fine Structure of the Nervous System: The Neurons and Supporting Cells. Philadelphia: W.B. Saunders.

Raisman G. 1969. Neuronal plasticity in the septal nuclei of the adult rat. Brain Res 14:25-48.

Raisman G. 1985. Synapse formation in the septal nuclei of adult rats. In: Cotman CW, editor. Synaptic Plasticity. New York: Guilford Press. p 13-38.

Raisman G, Field PM. 1973. A quantitative investigation of the development of collateral reinnervation after partial deafferentation of the septal nuclei. Brain Res 50:241-264.

Raisman G, Matthews MR. 1972. Degeneration and regeneration of synapses. In: Bourne GH, editor. Structure and Function of Nervous Tissue, Physiology II and Biochemistry II, Vol. IV. New York: Academic Press. p 61-104.

Tabakow P, Raisman G, Fortuna W, Czyz M, Huber J, Li D, Szewczyk P, Okurowski S, Miedzybrodzki R, Czapiga B, Salomon B, Halon A, Li Y, Lipiec J, Kulczyk A, Jarmundowicz W. 2014. Functional regeneration of supraspinal connections in a patient with transected spinal cord following transplantation of bulbar olfactory ensheathing cells with peripheral nerve bridging. Cell Transplant 23:1631-1655.

Tanaka M, Shih PY, Gomi H, Yoshida T, Nakai J, Ando R, Furuichi T, Mikoshiba K, Semyanov A, Itohara S. 2013. Astrocytic $\mathrm{Ca} 2+$ signals are required for the functional integrity of tripartite synapses. Mol Brain 6:6.

Watts RJ, Schuldiner O, Perrino J, Larsen C, Luo L. 2004. Glia engulf degenerating axons during developmental axon pruning. Curr Biol 14:678-684.

\section{LEGENDS}

Fig. 1

A dendritic shaft $(\mathrm{H})$ receives a synapse from a normal axon terminal (a, on the left). On the right the electron density and collapse indicates an axon terminal $(*)$ degenerating as a result of transection of its parent axon in the fimbria. The PAPs (yellow highlight): compare the very 
thin (50nm) PAP around the normal synapse with the swollen process invaginating (arrows) the degenerating synapse. s, postsynaptic thickenings. From Fig 2-3 in (Raisman, 1985).

\section{Fig. 2}

Major astrocytic hypertrophy directed (arrows) towards a degenerating axon terminal (*). From Fig. 25 in (Raisman and Matthews, 1972).

\section{Fig. 3A-C}

'Vacated' postsynaptic thickenings (s) apposed by hypertrophic astrocytic processes (arrows) containing the phagocytosed electron dense degenerating remains of detached axon terminals (*). From Figs 17-19 in (Raisman and Field, 1973).

Figs 1-3 are from the neuropil of the adult rat septal nuclei 2 days after transection of the hippocampal afferents in the fimbria. Scale bars $0.5 \mu \mathrm{m}$ (Figs 1,2) $0.25 \mathrm{um}$ (Fig. 3). Astrocytic processes are recognised in the electron microscope by their watery clear cytoplasm and sinuous irregular outlines (Peters, Palay, and Webster, 1976).

\section{Fig. 4A-E}

Stages illustrating the involvement (arrows) of perisynaptic astrocytic processes in synaptogenesis. In B, sensing degeneration; in $\mathrm{C}$, removing it and apposing the vacated postsynaptic thickening; and in $\mathrm{D}$, retracting as they guide in a new synapse. ax, presynaptic axon terminal; po, postsynaptic element with synaptic thickening (s); *, degeneration. 